\title{
Safety and efficacy of nivolumab applied at different dosage in the patients with relapsing Hodgkin lymphoma after allogeneic hematopoietic stem cell transplantation
}

\begin{abstract}
Kirill V. Lepik, Andrey V. Kozlov, Evgeniya S. Borzenkova, Marina O. Popova, Ivan S. Moiseev, Elena I. Darskaya, Asmik G. Gevorgyan, Luibov A. Tsvetkova, Sergey N. Bondarenko, Alexander L. Alyanskiy, Elena V. Kondakova, Natalya B. Mikhailova, Boris V. Afanasyev

R. M. Gorbacheva Memorial Institute of Children Oncology, Hematology and Transplantation, Chair of Hematology, Transfusiology and Transplantology, The First St. Petersburg State I. P. Pavlov Medical University, Roentgen St. 12; 197022, St. Petersburg, Russia
\end{abstract}

Dr. Kirill V. Lepik, R. M. Gorbacheva Memorial Institute of Children Oncology, Hematology and Transplantation,

I. P. Pavlov First St. Petersburg State Medical University,

Roentgen St. 12; 197022, St. Petersburg, Russia
Phone: +7 (911) 7839508

E-mail: lepikkv@gmail.com

\section{Summary}

Allogeneic hematopoietic cell transplantation (alloHSCT) is a potentially curative treatment for patients with relapsed and refractory Hodgkin lymphoma (HL) followed by long-term survival. However, relapse and progression of disease in the post-transplant period may occur in a substantial number of patients. nivolumab, an antibody blocking the programmed cell death receptor 1 (PD-1) has shown high efficiency in patients with HL in pre- and post-allo-HSCT setting. We have retrospectively assessed efficacy and toxicity of nivolumab as a single agent in seven HL patients relapsing after allo-HSCT using the drug at different doses $(0.5$ to $3 \mathrm{mg} / \mathrm{kg}$ body mass) administered every 2 weeks. We did not observe any cases of graft-versus-host disease (GVHD) after nivolumab initiation. An objective clinical response to the therapy was noted in all patients (100\%), at any dos- ing regimen. Complete metabolic response, as detected by PET/CT, was observed in two patients $(28.6 \%)$ treated at 0.5 and $1 \mathrm{mg} / \mathrm{kg}$. Three patients of seven (42.9\%) experienced grade 3-4 grade adverse events (AEs) from nivolumab, which included immune disorders. There was no correlation with nivolumab dosing regimen since severe AEs were documented in patients treated at $0.5,1$, or $3 \mathrm{mg} / \mathrm{kg}$. All the patients are alive by the time of evaluation, 4/7 patients had the disease relapse at a median of 7 months ( 5 to 9) after initiation of the treatment. nivolumab may represent an efficient therapeutic tool in patients with HL relapse after allo-HSCT, however, followed by a considerable toxicity in some cases.

\section{Keywords}

Hodgkin's lymphoma, allo-HSCT, relapse, immune checkpoints inhibitors, nivolumab, dosage. 


\section{Introduction}

Modern chemotherapy protocols and optimal radiotherapy allow to achieve stable remission in $\sim 80 \%$ newly diagnosed Hodgkin's lymphoma (HL) patients [1]. However, a proportion of HL patients has chemoresistant disease or relapse after initial objective response $[1,2]$. Further strategy with HL patients includes salvage treatment with high-dose chemotherapy followed by autologous stem cell transplantation (ASCT), and/or antibody-drug conjugate brentuximab vedotin $[3,4]$. The patients with failure of second-line treatment have poor prognosis and limited therapeutic options [5]. Allogeneic hematopoietic stem cell transplantation (allo-HSCT) is indicated for the patients with relapsed and refractory $(\mathrm{R} / \mathrm{R})$ disease, being able to improve long-term survival and control of the disease [5]. Although allo-HSCT is a potentially curative approach in these patients, a substantial fraction of patients develops relapses and disease progression in posttransplant period, showing strong dependence on the disease status at the time of transplantation [5].

The dysfunction of immune surveillance mechanisms with alteration of PD-1 ligand (PDL-1)-to-PD-1 signaling is considered a defining feature of classical Hodgkin's lymphoma [6]. nivolumab, a PD-1-blocking antibody, is an immune checkpoint inhibitor, showing high efficiency in patients with relapsed/refractory HL patients after ASCT and brentuximab vedotin treatment with benign toxicity profile. The most specific complications include autoimmune disorders such as pneumonitis, autoimmune hepatitis, hypothyroidism and other disorders [5]. Retrospective data demonstrated that nivolumab treatment for post-allo-HSCT may cause graft-versus-host disease (GVHD) manifestation and aggravation $[7,8,9]$. By contrary, some reports show no signs of GVHD after initiation of anti-PD-1 therapy [10]. Moreover, earlier observations show that, in HL patients after allo-HSCT, nivolumab may lead to profound clinical benefit even if applied at low doses [11]. With respect to previous reports we present retrospective results on seven HL patients relapsing after allo-HSCT subjected to nivolumab administered at different dosing regimens. In all the patients, nivolumab showed clinical efficiency with objective response and considerable toxicity, i.e., immune adverse effects, irrespective of nivolumab dosage, with no cases of GVHD manifestation.

\section{Patients and methods}

Our single-center study included seven patients (3 men and 4 women) with relapsed/refractory HL who underwent allo-HSCT. Their median age was 29 years ( 21 to 43 years old). Baseline characteristics of the patients are shown in Table 1. When entering the study, all the patients signed an informed consent for the use of their medical data for research purposes.

The median number of prior therapeutic lines was 9 (8 to 9) including autologous stem cell transplantation (performed in 5/7 patients), and allo-HSCT. Matched HLA-related siblings were used for 3 patients. Four patients had unrelated donors: three of them were HLA-identical and one with 9/10-locus mismatch. Peripheral blood stem cells were transplant- ed in four patients, and bone marrow, in rest of the cases. Six patients received reduced intensity conditioning (RIC): fludarabine $30 \mathrm{mg} / \mathrm{m}^{2} /$ bendamustine $130 \mathrm{mg} / \mathrm{m}^{2}$ per day for 3 days (FluBe) regimen was used in 3 patients, Flu/2 Gy TBI, in 2 patients, and Flu/ $8 \mathrm{mg} / \mathrm{kg}$ busulfan was used in 1 case. In 5/7 patients, the post-transplant cyclophosphamide based regimen was used for GVHD prophylaxis, i.e., cyclophosphamide $50 \mathrm{mg} / \mathrm{kg}$ on day +3 and +4 after alloHSCT (PTC) in 2 patients, PTC in combination with tacrolimus started on day +5 (PTC-Tx) in 1 patient, PTC-Tx with addition of mycophenolate mofetil (MMF) in 2 patients, methotrexate/ tacrolimus in 1 case, and antithymocyte globulin/methotrexate/MMF/cyclosporine $\mathrm{A}$ in 1 patient. Objective response determined as CR or PR before allo-HSCT was documented in four patients ( $3 \mathrm{CR}, 1 \mathrm{PR}$ ), two patients received transplant during the disease progression. Acute GVHD was reported in 6 patients, with no severe (grade III-IV) cases, and 3 patients had a limited chronic skin GVHD. Median time between the allo-HSCT and disease relapse/progression was 3.3 months (1.5-10). As salvage therapy after allo-HSCT, all patients have received the treatment with brentuximab vedotin, six of them received treatment with bendamustine. Five patients received donor lymphocyte infusions before nivolumab initiation. Median time from allo-HSCT to first injection of nivolumab was 26.7 months (range 7-42.4). One patient has received nivolumab before allo-HSCT, but treatment was discontinued due to grade 4 adverse event (bacterial meningitis). Transplantation modalities and complications are shown in Table 2.

By the moment of nivolumab initiation, six patients had disease progression, one patient had stabilization of disease, 6/7 of patients presented with extranodal disease and 3/7 with B-symptoms. None of the patients had signs of GVHD at the moment of treatment initiation.

Nivolumab was given as monotherapy at the dose of $3 \mathrm{mg} /$ $\mathrm{kg}$ of body weight intravenously every two weeks for two patients. Due to concerns regarding the manifestation of GVHD and immune-related adverse events, the dose were reduced to $1 \mathrm{mg} / \mathrm{kg}$ and to the dose of $0.5 \mathrm{mg} / \mathrm{kg}$ i.v. every two weeks for 1 patient and for 4 patients, respectively. A median number of nivolumab injections was 7 ( 1 to 20). The treatment efficacy was assessed by total body PET/CT scan [12] every 3 months after nivolumab initiation or earlier in the event of treatment discontinuation. Toxicities were graded retrospectively according to the National Cancer Institute Common Toxicity Criteria for AEs (version 4.03).

\section{Results}

\section{Treatment efficiency}

Response to the nivolumab-based therapy was evaluated at a median follow-up time of 14.5 (3.3-22.5) months. Objective response was noted in all the patients at either nivolumab dosage. Complete metabolic response was observed in two patients $(28.6 \%)$ treated with, respectively, 0.5 and $1 \mathrm{mg} / \mathrm{kg}$ of the drug. The rest of this group exhibited partial clinical responses. The maximal response and tumor mass reduction at the best response are shown in Fig. 1. and Fig. 2. The specific B symptoms of lymphoma reported before the therapy 
Table 1. Baseline charasteristics of the patients

\begin{tabular}{|l|l|}
\hline Number of patients (\%) & $7(100)$ \\
\hline Median age, years (range) & $29(21-43)$ \\
\hline $\begin{array}{l}\text { Gender, no. (\%) } \\
\text { Female }\end{array}$ & $4(57.1)$ \\
Male & $3(42.9)$ \\
\hline Response to induction, no (\%): & $5(71.4)$ \\
Primary chemoresistant & $1(14.3)$ \\
\hline Early relapse & $8.9(8-9)$ \\
\hline Number of prior therapy lines, median (range), including: & $3(42.9)$ \\
Prior radiation therapy, no (\%) & $5(71.4)$ \\
Prior autologous transplantation, no. (\%) & $7(100)$ \\
Prior treatment with brentuximab-vedotin, no. (\%) & $7(100)$ \\
\hline Prior treatment with bendamustine, no. (\%) & $6(85.7)$ \\
\hline Status at the start of treatment with Nivo, no (\%): & $1(14.3)$ \\
\hline relapse/progression & $5(71.4)$ \\
stabilization & $2(28.6)$ \\
\hline ECOG performance status score, no. (\%) & $3(42.9)$ \\
\hline$\leq 1$ & $6(85.7)$ \\
\hline 2 & $3.3(1.5-10)$ \\
\hline B-symptoms at the start of treatment with Nivo, no (\%) & $26.7(7-42.4)$ \\
\hline Extranodal disease, no (\%) & $14(1.2-24.7)$ \\
\hline Median time from allo-HCT to relapse/progression, months (range) & \\
\hline Median time from allo-HCT to nivolumab initiation, months (range) & \\
\hline Median time from last DLI to nivolumab initiation, months (range) & \\
\hline
\end{tabular}

were resolved in two of three patients. The objective response was observed after a median of 6 (1-6) nivolumab injections. Four patients (57\%) have experienced the disease progression at a median of 6.7 months (5 to 8.5). Two of these patients were re-treated with the same dose of nivolumab, thus allowing to achieve an objective response (CR) in one patient. After monotherapy with nivolumab, three patients underwent further treatment, with addition of bendamustine or other cytostatic agents. At the time of this report, three patients $(42.9 \%)$ still receive the nivolumab monotherapy. Clinical outcomes are presented in Table 3 and Fig. 3.

\section{Toxicity}

All the patients were alive at the time of report and were subject to the safety analysis. During nivolumab treatment, $3 / 7(42.9 \%)$ of the patients experienced grade 3-4 adverse events (AEs), which included two cases of aseptic meningitis (28.6\%) and one case of autoimmune hepatitis, autoimmune hypophysitis. This adverse events manifested after median of 2 (1-2) infusions of the drug. Due to severe adverse events, the nivolumab treatment was discontinued, and patients received short courses of glucocorticoids $(1 \mathrm{mg} / \mathrm{kg}$ methylprednisolone) with complete resolution of the event. There was no correlation with nivolumab dosing regimen, since severe AEs were observed in patients with different drug dosage $(0.5,1$, or $3 \mathrm{mg} / \mathrm{kg}$ of body weight). There were no cases of GVHD onset. Notably, the patient who had discontinued nivolumab before allo-HSCT had no adverse events in post-transplant setting. Two patients who discontinued nivolumab treatment due to AE's, received retreatment after the disease relapse. In one patient with meningitis and hypophisitis, no AE recurrence was revealed later, in another case, a recurrence of autoimmune hepatitis was noted after 2 infusions during the first retreatment. The therapy was again discontinued, and the patient received glucocorticoids followed by complete resolution of hepatitis. The second retreatment was performed with addition of low-dose glucocorticoids in both patients, without AE signs observed.

\section{Discussion}

Allo-HSCT is a potentially curative treatment strategy for relapsed and refractory HL patients. Despite novel therapeutic modalities in HL, allogeneic HSCT is remaining an important option. Transplant-related mortality continues to decline owing to lower intensity preparative regimens [13], improved GVHD prophylaxis [5] and novel treatment modalities [4]. At the same time, HL relapse continues to present a significant problem [5]. Therapeutic options are limited in this severely pre-treated group of patients. Common treatment modalities in patients with relapse after allo-HSCT include brentuximab vedotin [14], donor lymphocyte infusions [15] and chemotherapy regimens, such as bendamustine [16] and drug combinations [17-19] with modest results. Therefore, improved post allo-HSCT treatment strategies are needed. Based on biological features of $\mathrm{HL}$, and described 
Table 2. Transplantation modalities and complications

\begin{tabular}{|c|c|c|c|c|c|c|c|}
\hline Patients, no & 1 & 2 & 3 & 4 & 5 & 6 & 7 \\
\hline $\begin{array}{l}\text { Status before } \\
\text { allo-HSCT }\end{array}$ & PD & CR & PR & Stabilization & CR & CR & PD \\
\hline Donor type & MRD & MUD & MUD & MRD & MMUD & MRD & MUD \\
\hline Conditioning & Flu-Be/RIC & Flu+TBI/RIC & Flu-TBI/RIC & Flu-Be/RIC & Flu-Tre/MAC & Flu-Be/RIC & Flu-Bu/RIC \\
\hline $\begin{array}{l}\text { GVHD } \\
\text { prophylaxis }\end{array}$ & PTC & PTC-Tx-MMF & PTC-Tx-MMF & MTX-Tx & ATG-MTX-CSA-MMF & PTC & PTC-Tx \\
\hline $\begin{array}{l}\text { Source of stem } \\
\text { cells }\end{array}$ & BM & PBSC & PBSC & BM & PBSC & BM & PBSC \\
\hline $\begin{array}{l}\text { History of acute } \\
\text { GVHD/localiza- } \\
\text { tion, grade }\end{array}$ & $\begin{array}{l}\text { Skin, } \\
\text { I grade }\end{array}$ & $\begin{array}{l}\text { Skin, } \\
\text { I grade }\end{array}$ & $\begin{array}{l}\text { Skin, I-II } \\
\text { grade }\end{array}$ & $\begin{array}{l}\text { Skin, } \\
\text { I grade }\end{array}$ & Gut, I-II grade & No & $\begin{array}{l}\text { Skin, I -II } \\
\text { grade }\end{array}$ \\
\hline $\begin{array}{l}\text { History of } \\
\text { chronic GVHD/ } \\
\text { localization, } \\
\text { grade }\end{array}$ & No & $\begin{array}{l}\text { Skin, gut I-II } \\
\text { grade }\end{array}$ & $\begin{array}{l}\text { Skin, } \\
\text { I-II grade }\end{array}$ & $\begin{array}{l}\text { Skin, mucosa, } \\
\text { I grade }\end{array}$ & No & No & No \\
\hline $\begin{array}{l}\text { Response after } \\
\text { alloHSCT }\end{array}$ & PR & CR & PR & PD & PD & PD & PD \\
\hline $\begin{array}{l}\text { Treatment } \\
\text { modalities used } \\
\text { after alloSCT }\end{array}$ & $\begin{array}{l}\text { BV/DLI/ } \\
\text { Chemo }\end{array}$ & $\begin{array}{l}\text { BV/DLI/ } \\
\text { Chemo }\end{array}$ & $\begin{array}{l}\text { BV/ DLI/ } \\
\text { Chemo }\end{array}$ & $\begin{array}{l}\text { BV/DLI/ } \\
\text { Chemo }\end{array}$ & BV/Chemo & $\begin{array}{l}\text { BV/DLI/ } \\
\text { Chemo }\end{array}$ & BV \\
\hline DLI, no. & 5 & 7 & 5 & 7 & No & 4 & No \\
\hline
\end{tabular}

mechanisms of graft-versus-lymphoma (GVL) effect, the enhancement of GVL with PD-1 blockade was proposed and demonstrated with several murine models $[20,21]$ with no GVHD aggravation, and confirmed by early clinical observations [22, 23]. Two retrospective studies [7,9] of nivolumab salvage treatment in HL relapse after allo-HSCT demonstrate profound activity of this drug (ORR $77 \%-95 \%$, CR $42 \%-50 \%$ ), but also significant toxicity, with high rate of GVHD manifestation (30\%-50\%) including steroid-refractory and lethal cases of GVHD. The authors conclude that administration of anti-PD-1 after allo-HSCT should be done with extreme caution. This multicenter retrospective studies included mixed population of patients with different types of conditioning regimens and GVHD prophylaxis. Therefore, a strong need for prospective studies with standardized preparative regimens is required.

Another aspect addressed in our retrospective analysis is the dosing regimen for nivolumab. Most data regarding efficiency of nivolumab after allo-HSCT were obtained at a standard dose of $3 \mathrm{mg} / \mathrm{kg}$ every two weeks $[7,9]$. Meanwhile, its pharmacokinetic studies reveal that the PD-1 peripheral receptor occupancy was saturated at doses as low as $0.3 \mathrm{mg} / \mathrm{kg}$. There are also reports of efficient treatment with lower doses of the drug $(0.5 \mathrm{mg} / \mathrm{kg})$ in post allo-HSCT setting [11]. Thus, there is rationale for testing different doses of nivolumab in patients after allo-HSCT.
Here we present a retrospective analysis of 7 patients with HL relapse after allo-HSCT treated with nivolumab at different dosing regimens $(0,5-3 \mathrm{mg} / \mathrm{kg})$. All the patients were severely pre-treated with previous therapy (a median of 9 infusions). Most of the patients included into the study (5/7) received the posttransplant cyclophosphamide (PTC)-based GVHD prophylaxis. We demonstrate high efficiency of treatment with 100\% ORR in all assessed patients and 28.6\% CR rate, irrespective of the nivolumab dosing regimen. Despite high initial response rates, 4 of 7 patients (57\%) have experienced disease progression at the median of 6.7 months. Importantly, nivolumab retreatment in two patients was followed by CR achievement in one patient, and clinical improvement in both cases. After median follow up of 14.5 (3.3 to 22.5 ) months, all the patients are alive with good quality of life.

We did not observe any GVHD onset or exacerbation in our group of patients, possibly due to use of PTC based GVHD prophylaxis regimen and long median time of treatment initiation after alloSCT $(26.7 \mathrm{mo}), 3 / 7$ patients were experienced grade 3-4 immune $\mathrm{AE}$ including aseptic meningitis, hypophysitis and hepatitis. Whether the hepatic involvement was due the autoimmune hepatitis or GVHD is not completely clear, as clinical and histologic differences between GVHD and anti-PD-1 toxicity are not strictly defined. We consider our case of hepatic toxicity as hepatitis associated with anti-PD-1 drug treatment, because it presented with 


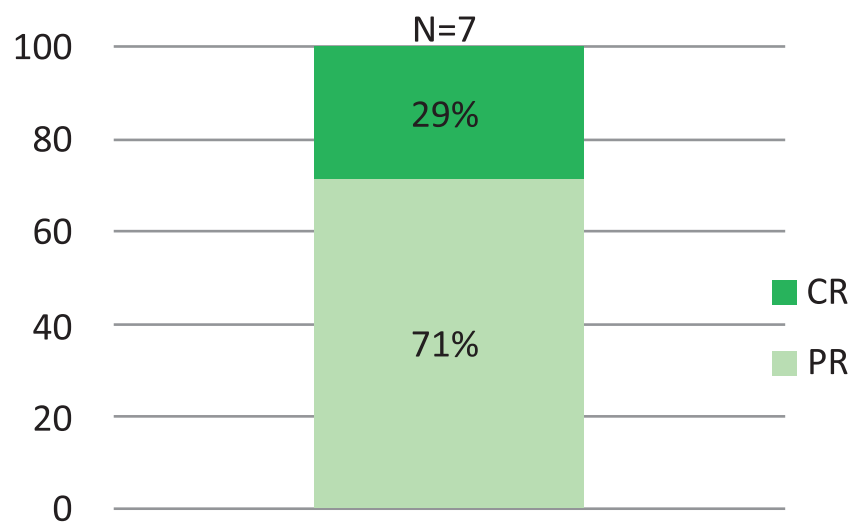

Figure 1. Best response rates following nivolumab treatment (7 cases). CR, complete remission, PR, partial remission

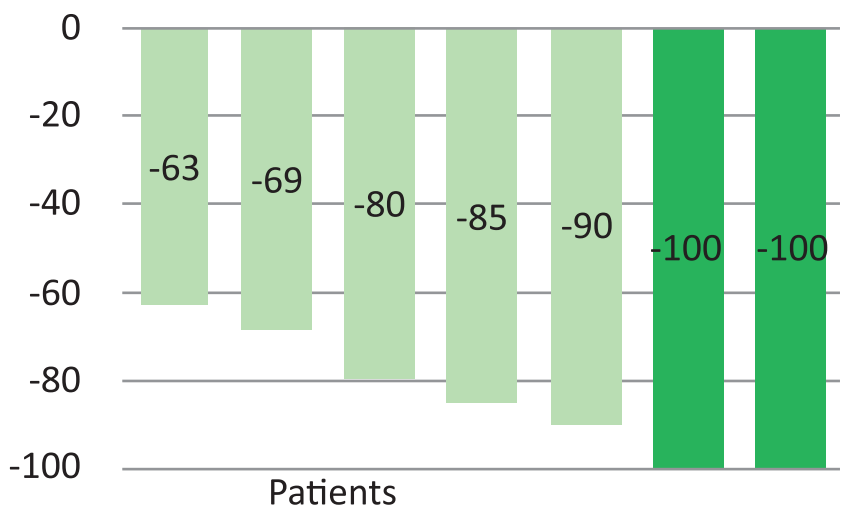

Figure 2. Maximal changes from baseline in target lesion. The values shown indicate maximal registered tumor reduction
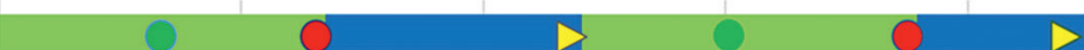

OS

$6)$
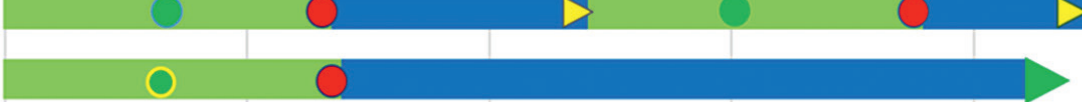

0
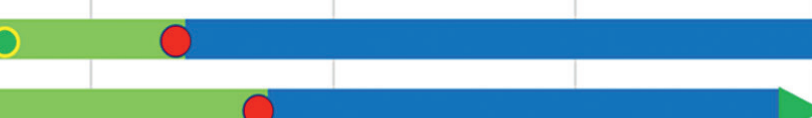

0

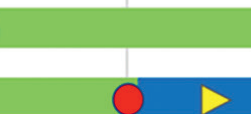

0

3

(2)

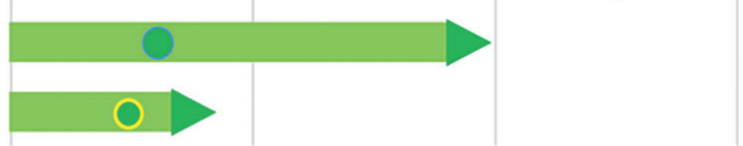

Months

Figure 3. Response characteristics during observation. Numbers on the left axis represent the patient number corresponding to Table 2. OS overall survival, PFS progression free survival, CR complete remission achievement, PR moment of partial remission achievement, PD/Relapse time point of registered progression of relapse, Retreatment time point of starting repeated treatment

Table 3. Clinical outcomes following treatment with different doses of Nivolumab

\begin{tabular}{|l|l|l|l|l|l|l|l|}
\hline Patient, no & 1 & 2 & 3 & 4 & 5 & 6 & 7 \\
\hline Dose, mg/kg & 0,5 & 0,5 & 0,5 & 1 & 3 & 3 & 0,5 \\
\hline $\begin{array}{l}\text { Injections } \\
\text { in monotherapy, no }\end{array}$ & 2 & 9 & 6 & 1 & 25 & 2 & 6 \\
\hline Best response & PR & PR & CR & CR & PR & PR & PR \\
\hline AEs 3-4 grade & $\begin{array}{l}\text { Autoimmune } \\
\text { hepatitis }\end{array}$ & No & No & $\begin{array}{l}\text { Hypophysitis } \\
\text { Aseptic } \\
\text { meningitis }\end{array}$ & No & $\begin{array}{l}\text { Aseptic } \\
\text { meningitis }\end{array}$ & No \\
\hline Current status & Relapse & $\begin{array}{l}\text { Still in } \\
\text { response }\end{array}$ & $\begin{array}{l}\text { Still in } \\
\text { response }\end{array}$ & Relapse & Relapse & Relapse & $\begin{array}{l}\text { Still in } \\
\text { response }\end{array}$ \\
\hline Efficient retreatment & No & n/a & n/a & Yes & n/a & n/a & n/a \\
\hline Alive & Yes & Yes & Yes & Yes & Yes & Yes & Yes \\
\hline $\begin{array}{l}\text { Currently receceiving } \\
\text { Nivo }\end{array}$ & Yes & Yes & No & Yes & No & No & No \\
\hline
\end{tabular}


asymptomatic, profound increase in transaminases, while bilirubin level was within reference ranges during the entire observation period, which corresponds to common hepatic AEs induced by PD-1/PD-L1 inhibitors presenting as asymptomatic increase of AST and ALT, and total bilirubin in rare instances [24].

Despite severity of the observed immune AE's, they regressed shortly after nivolumab discontinuation and initiation of glucocorticoid therapy. Therefore, anti-PD-1 antibodies after allo-HSCT should be administered with caution, and careful monitoring of patient is needed, especially during the first month of anti-PD-1 treatment.

Previous reports of treatment with ipilimumab [25, 26] and lower doses of anti-PD-1 antibodies [11], suggested a dose-dependent or context-dependent risk of developing toxicity after the apoptosis checkpoint blockade. During our analysis we did not observed the dependence of the toxicity and effect from nivolumab dosage. Complete metabolic response observed in two patients with 0.5 and $1 \mathrm{mg} / \mathrm{kg}$ dosing regimen, and severe AEs was experienced in patients with $0.5,1,3 \mathrm{mg} / \mathrm{kg}$.

The results obtained with anti-PD therapy of Hodgkin's disease should be compared with efficiency of Brentuximab, an immunotoxic drug targeted for CD30 antigen on tumor cells [27]. It proved to be highly efficient in resistant/relapsed cases of HD being currently under extensive trials [28-30]. Its combined effects with anti-PD drugs deserve further studies.

\section{Conclusion}

Our retrospective analysis of nivolumab treatment at different single dosages concerned post-allo-HSCT patients who developed HL relapse. We have confirmed clinical efficacy of nivolumab, however, with induction of severe-grade 3-4 immune AEs in three patients subjected to different dosing regimens $(0.5,1,3 \mathrm{mg} / \mathrm{kg})$, but without any documented GVHD cases. The prospective studies are warranted, aiming for establishment of optimal dosing regimens, as well as potential effects of conditioning and GVHD prophylaxis upon the risks and benefits of nivolumab treatment after allo-HSCT.

\section{Conflict of interest}

The authors report no conflicts of interest.

\section{References}

1. Canellos GP, Anderson JR, Propert KJ, Nissen N, Cooper MR, Henderson ES, Green MR, Gottlieb A, Peterson BA. Chemotherapy of advanced Hodgkin's disease with MOPP, ABVD, or MOPP alternating with ABVD. N Engl J Med. $1992 ; 327(21): 1478-1484$.

2. Diehl V, Franklin J, Pfreundschuh M, Lathan B, Paulus U, Hasenclever D, Tesch H, Herrmann R, Dörken B, Müller-Hermelink HK, Dühmke E, Loeffler M; German Hodgkin's Lymphoma Study Group. Standard and increased-dose BEACOPP chemotherapy compared with COPP-ABVD for advanced Hodgkin's disease. N Engl J Med. 2003;348(24):2386-2395.
3. Rancea M, Monsef I, von Tresckow B, Engert A, Skoetz N. High-dose chemotherapy followed by autologous stem cell transplantation for patients with relapsed/refractory Hodgkin lymphoma, Cochrane Database Syst Rev. 2013; (6):CD009411

4. Zinzani PL, Viviani S, Anastasia A., Vitolo U., Luminari S, Zaja F, Corradini P, Spina M, Brusamolino E, Gianni A, Santoro A, Botto B, Derenzini E, Pellegrini C, Argnani L. Brentuximab Vedotin in relapsed/refractory Hodgkin's lymphoma: The Italian experience and results of its use in daily clinical practice outside clinical trials. Haematologica. 2013; 98: 1232-1236.

5. Martínez C, Gayoso J, Canals C, Finel H, Peggs K, Dominietto A, Castagna L, Afanasyev B, Robinson S, Blaise D, Corradini P, Itälä-Remes M, Bermúdez A, Forcade E, Russo D, Potter M, McQuaker G, Yakoub-Agha I, Scheid C, Bloor A, Montoto S, Dreger P, Sureda A. Post-transplantation cyclophosphamide-based haploidentical transplantation as alternative to matched sibling or unrelated donor transplantation for Hodgkin lymphoma: A registry study of the Lymphoma Working Party of the European Society for Blood and Marrow Transplantation. J Clin Oncol. 2017;35(30):3425-3432.

6. Roemer MGM, Advani RH, Ligon AH, Natkunam Y, Redd RA, Homer H, Connelly CF, Sun HH, Daadi SE, Freeman GJ, Armand P, Chapuy B, de Jong D, Hoppe RT, Neuberg DS, Rodig SJ, Shipp MA. PD-L1 and PD-L2 genetic alterations define classical Hodgkin lymphoma and predict outcome. J Clin Oncol. 2016;34(23):2690-2697.

7. Herbaux C, Gauthier J, Brice P, Drumez E, Ysebaert L, Doyen H, Fornecker L, Bouabdallah K, Manson $\mathrm{G}$, Ghesquières $\mathrm{H}$, Tabrizi R, Hermet E, Lazarovici J, Thiebaut-Bertrand A, Chauchet A, Demarquette H, Boyle E, Houot R, Yakoub-Agha I, Morschhauser F. Efficacy and tolerability of nivolumab after allogeneic transplantation for relapsed Hodgkin's lymphoma. Blood. 2017; 129(18):24712478.

8. El Cheikh J, Massoud R, Abudalle I, Haffar B, Mahfouz R, Kharfan-Dabaja MA, Jisr T, Mougharbel A, Ibrahim A, Bazarbachi A. Nivolumab salvage therapy before or after allogeneic stem cell transplantation in Hodgkin lymphoma. Bone Marrow Transplant. 2017; 52(7):1074-1077.

9. Haverkos BM, Abbott D, Hamadani M, Armand P, Flowers ME, Merryman R, Kamdar M, Kanate AS, Saad A, Mehta A, Ganguly S, Fenske TS, Hari P, Lowsky R, Andritsos L, Jagasia M, Bashey A, Brown S, Bachanova V, Stephens D, Mineishi S, Nakamura R, Chen YB, Blazar BR, Gutman J, Devine SM. PD-1 blockade for relapsed lymphoma post-allogeneic hematopoietic cell transplant: high response rate but frequent GVHD. Blood. 2017;130(2):221-228.

10. Villasboas JC, Ansell SM, Witzig TE. Targeting the PD-1 pathway in patients with relapsed classic Hodgkin lymphoma following allogeneic stem cell transplant is safe and effective. Oncotarget. 2016; 7: 13260-13264.

11. Onizuka M, Kojima M, Matsui K, Machida S, Toyosaki M, Aoyama Y, Kawai H, Amaki J, Hara R, Ichiki A, Ogawa Y, Kawada H, Nakamura N, Ando K. Successful treatment with 
low-dose nivolumab in refractory Hodgkin lymphoma after allogeneic stem cell transplantation. Int J Hematol. 2017; 106(1):141-145.

12. Cheson BD, Fisher RI, Barrington SF, Cavalli F, Schwartz LH, Zucca E, Lister TA et al. Recommendations for initial evaluation, staging, and response assessment of Hodgkin and non-Hodgkin lymphoma: The Lugano Classification. J Clin Oncol. 2014; 32(27):3059-3068.

13. Khouri IF, Wei W, Korbling M, Turturro F, Ahmed S, Alousi A, Anderlini P, Ciurea S, Jabbour E, Oran B, Popat UR, Rondon G, Bassett RL Jr, Gulbis A. BFR (bendamustine, fludarabine, and rituximab) allogeneic conditioning for chronic lymphocytic leukemia/lymphoma: reduced myelosuppression and GVHD. Blood. 2014; 124(14):2306-2312.

14. Carlo-Stella C, Ricci F, Dalto S, Mazza R, Malagola M, Patriarca F, Viviani S, Russo D, Giordano L, Castagna L, Corradini $\mathrm{P}$, Santoro A. Brentuximab vedotin in patients with Hodgkin lymphoma and a failed allogeneic stem cell transplantation: results from a named patient program at four Italian centers. Oncologist. 2015;20(3):323-328.

15. Anderlini P, Saliba R, Acholonu S, Okoroji GJ, Ledesma C, Andersson BS, Jones R, Popat UR, Hosing CM, Nieto Y, Qazilbash MH, Ueno NT, Giralt SA, de Lima MJ, Champlin RE. Donor leukocyte infusions in recurrent Hodgkin lymphoma following allogeneic stem cell transplant: 10-year experience at the MD Anderson Cancer Center. Leuk Lymphoma. 2012;53(6):1239-1241.

16. Anastasia A, Carlo-Stella C, Corradini P, Salvi F, Rusconi C, Pulsoni A, Hohaus S, Pregno P, Viviani S, Brusamolino E, Luminari S, Giordano L, Santoro A. Bendamustine for Hodgkin lymphoma patients failing autologous or autologous and allogeneic stem cell transplantation: a retrospective study of the Fondazione Italiana Linfomi. Br. J. Haematol. 2014;166(1):140-142.

17. Theurich S, Malcher J, Wennhold K, Shimabukuro-Vornhagen A, Chemnitz J, Holtick U, Krause A, Kobe C, Kahraman D, Engert A, Scheid C, Chakupurakal G, Hallek M, von Bergwelt-Baildon M. Brentuximab vedotin combined with donor lymphocyte infusions for early relapse of Hodgkin lymphoma after allogeneic stem-cell transplantation induces tumor-specific immunity and sustained clinical remission. J Clin Oncol. 2013;31(5):e59-63. DOI: 10.1200/ JCO.2012.43.6832

18. Tsirigotis P, Danylesko I, Gkirkas K., Shem-Tov N, Yerushalmi R, Stamouli M, Avigdor A, Spyridonidis A, Gauthier J, Goldstein G, Apostolidis J, Mohty M, Shimoni A, Nagler A. Brentuximab vedotin in combination with or without donor lymphocyte infusion for patients with Hodgkin lymphoma after allogeneic stem cell transplantation. Bone Marrow Transplant. 2016;51(10):1313-1317.

19. Sala E, Crocchiolo R, Gandolfi S, Bruno-Ventre M, Bramanti S, Peccatori J, Sarina B, Corti C, Ciceri F, Santoro A, Marktel S, Castagna L. Bendamustine combined with donor lymphocytes infusion in Hodgkin's lymphoma relapsing after allogeneic hematopoietic stem cell transplantation. Biol. Blood Marrow Transplant. 2014;20(9):1444-1447.
20. Koestner W, Hapke M, Herbst J., Klein C, Welte K, Fruehauf J, Flatley A, Vignali DA, Hardtke-Wolenski M, Jaeckel E, Blazar BR, Sauer MG. PD-L1 blockade effectively restores strong graft-versus-leukemia effects without graftversus-host disease after delayed adoptive transfer of T-cell receptor gene engineered allogeneic CD8+ T cells. Blood. 2011;117(3):1030-1041.

21. Michonneau D, Sagoo P, Breart B, Garcia Z, Celli S, Bousso P. The PD-1 axis enforces an anatomical segregation of CTL activity that creates tumor niches after allogeneic hematopoietic stem cell transplantation. Immunity. 2016;44(1):143-154.

22. Angenendt L, Schliemann C, Lutz M, Rebber E, Schulze $A B$, Weckesser M, Stegger L, Schäfers M, Groth C, Kessler T, Lenz G, Stelljes M, Berdel WE. Nivolumab in a patient with refractory Hodgkin's lymphoma after allogeneic stem cell transplantation. Bone Marrow Ttransplant. 2016;51(3):443445.

23. Yared JA, Hardy N, Singh Z, Hajj S, Badros AZ, Kocoglu M, Yanovich S, Sausville EA, Ujjani C, Ruehle K, Goecke C, Landau M, Rapoport AP. Major clinical response to nivolumab in relapsed/refractory Hodgkin lymphoma after allogeneic stem cell transplantation. Bone Marrow Transplant. 2016;51(6):850- 852.

24. Zhang X, Ran Y, Wang K, Zhu Y, Li J. Incidence and risk of hepatic toxicities with PD-1 inhibitors in cancer patients: a meta-analysis. Drug Design, Development and Therapy. 2016; 10:3153-3161.

25. Bashey A, Medina B, Corringham S, Pasek M, Carrier E, Vrooman L, Lowy I, Solomon SR, Morris LE, Holland HK, Mason JR, Alyea EP, Soiffer RJ, Ball ED. CTLA4 blockade with ipilimumab to treat relapse of malignancy after allogeneic hematopoietic cell transplantation. Blood. 2009;113(7):1581-1588.

26. Davids MS, Kim HT, Bachireddy P, Costello C, Liguori R, Savell A, Lukez AP, Avigan D, Chen YB, McSweeney P, LeBoeuf NR, Rooney MS, Bowden M, Zhou CW, Granter SR, Hornick JL, Rodig SJ, Hirakawa M, Severgnini M, Hodi FS, Wu CJ, Ho VT, Cutler C, Koreth J, Alyea EP, Antin JH, Armand P, Streicher H, Ball ED, Ritz J, Bashey A, Soiffer RJ. Ipilimumab for patients with relapse after allogeneic transplantation. New Engl J Med. 2016;375(2):143-153.

27. King RL, Howard MT, Bagg A. Hodgkin Lymphoma: Pathology, pathogenesis, and a plethora of potential prognostic predictors. Anat Pathol. 2014;21:12-25.

28. Younes A, Gopal AK, Smith SE, Ansell SM, Rosenblatt JD, Savage KJ, Ramchandren R, Bartlett NL, Cheson BD, de Vos S, Forero-Torres A, Moskowitz CH, Connors JM, Engert A, Larsen EK, Kennedy DA, Sievers EL, Chen R. Results of a pivotal phase II Study of Brentuximab Vedotin for patients with relapsed or refractory Hodgkin's lymphoma. J Clin Oncol. 2012;30(18):2183-2189.

29. Younes A, Santoro A, Shipp M, Zinzani PL, Timmerman JM, Ansell S, Armand P, Fanale M, Ratanatharathorn V, Kuruvilla J, Cohen JB, Collins G, Savage KJ, Trneny M, Kato K, Farsaci B, Parker SM, Rodig S, Roemer MG, Ligon AH, 
Engert A. Nivolumab for classical Hodgkin's lymphoma after failure of both autologous stem-cell transplantation and brentuximab vedotin: a multicentre, multicohort, single-arm phase 2 trial. Lancet Oncol. 2016;17(9):1283-1294.

30. Afanasyev BV, Moiseev IS, Alekseev SM, Mikhailova NB, Kondakova EV, Ilyin NV, Belyaev AM. Multicenter prospective escalation-de-escalation PET-guided clinical study in classical type Hodgkin disease in the North-East of Russian Federation (RNWOHG-HD1): rationale and design. Cell Ther Transplant. 2017; 6(4): 76-81.

\title{
Безопасность и эффективность ниволумаба в различных режимах дозирования у пациентов с рецидивами классической лимфомы Ходжкина после аллогенной трансплантации гемопоэтических стволовых клеток
}

\author{
Кирилл В. Лепик, Андрей В. Козлов, Евгения С. Борзенкова, Марина О. Попова, Иван С. Моисеев, \\ Елена И. Дарская, Асмик Г. Геворгян, Любовь А. Цветкова, Сергей Н. Бондаренко, Александр Л. Алянский, \\ Елена В. Кондакова, Наталья Б. Михайлова, Борис В. Афанасьев \\ НИИ детской онкологии, гематологии и трансплантологии им. Р. М. Горбачевой; кафедра гематологии, трансфузиологии \\ и трансплантологии, Первый Санкт-Петербургский государственный медицинский университет им. И. П. Павлова, \\ Санкт-Петербург, Российская Федерация
}

\section{Резюме}

Аллогенная трансплантация гемопоэтических клеток (алло-ТГСК) обладает потенциалом излечения пациентов с рецидивирующей и рефрактерной лимфомой Ходжкина (p/p ЛХ). Несмотря на это, рецидив и прогрессирование заболевания в посттрансплантационном периоде происходит у значимой части пациентов. Ниволумаб представляет собой препарат моноклональных антител, блокирующих рецептор программируемой гибели 1 (PD-1), который показал высокую эффективность у пациентов с p/p ЛХ перед и после алло-ТГСК. Мы ретроспективно оценили эффективность и токсичность терапии ниволумабом в монорежиме у 7 пациентов с рецидивами ЛХ после алло-ТГСК в различных режимах дозирования (0,5-3 мг/кг) с кратностью введения каждые 2 недели. В нашей группе не было отмечено случаев возникновения РТПХ на фоне лечения ниволумабом. Вне зависимости от режима дозирования, объективный ответ на терапию отмечен у всех пациентов (100\%). Полный метаболический ответ наблюдался у двух пациентов (28.6\%) с режимом дозирования 0.5 и 1 мг/кг. Во время лечения ниволумабом у $3 / 7$ (42,9\%) пациентов наблюдались иммунные нежелательные явления (НЯ) 3-4 степени тяжести. Тяжелые НЯ отмечались у пациентов с различными режимами дозирования $(0,5 ; 1$ или 3 мг/кг. Отмечался полный регресс НЯ на фоне терапии глюкокортикостероидами. Все пациенты были живы на момент анализа. У 4/7 пациентов отмечался рецидив заболевания через 7 (5-9) месяцев после начала терапии ниволумабом. Таким образом, ниволумаб может быть эффективным терапевтическим подходом у пациентов с рецидивом ЛХ после алло-ТГСК, с риском проявления иммунной токсичности в ряде случаев.

\section{Ключевые слова}

Лимфома Ходжкина, аллогенная трансплантация гемопоэтических клеток, рецидив, ингибиторы контрольных точек, ниволумаб, дозировка. 